Journal of Maternal and Child Health (2019), 4(3): 136-145

https://doi.org/10.26911/thejmch.2019.04.03.01

\title{
Contextual Effect of Community Health Center on Low Birtweight in East Lombok, Nusa Tenggara Barat
}

\author{
Baiq Zulvita Rahayu'), Uki Retno Budihastuti²), Setyo Sri Rahardjo3) \\ ${ }^{1)}$ Masters Program in Public Health, Universitas Sebelas Maret \\ ${ }^{2}$ )Department of Obstetrics and Gynecology, Dr. Moewardi Hospital, Surakarta \\ 3)Faculty of Medicine, Universitas Sebelas Maret, Surakarta
}

\begin{abstract}
Background: Low birth weight babies (LBW) become a global health problem. Studies into the contextual effect of community health center on LBW are lacking. This study aimed to determine the contextual effect of community health center on the determinants of low birth weight in East Lombok, Indonesia using multilevel analysis.

Subjects and Method: This was an analytic observational study with a cross sectional design. It was conducted in East Lombok, from September to November 2018. A total sample of 200 infants from 25 community health centers was selected by random sampling. The dependent variable was LBW. The independent variables were maternal age, maternal education, family income, prenatal stress, maternal nutritional status, exposure to cigarette smoke, maternal occupation, social support, and social capital. The data were collected from the medical record and questionnaire. The data were analyzed by a multilevel multiple logistic regression analysis.

Results: Maternal age $<20$ or $\geq 35$ years $(b=2.60 ; 95 \% \mathrm{CI}=0.96$ to $4.25 ; \mathrm{p}=0.002)$, prenatal stress $(\mathrm{b}=1.30 ; 95 \% \mathrm{CI} 95 \%=0.01$ to $2.57 ; \mathrm{p}=0.048)$, and exposure to cigarette smoke $(\mathrm{b}=1.57 ; \mathrm{CI}$ $95 \%=0.37$ to $2.76 ; \mathrm{p}=0.010$ ) increased the risk of LBW. LBW decreased with high maternal education ( $\mathrm{b}=-1.38 ; 95 \% \mathrm{CI}=-2.60$ to $-0.15 ; \mathrm{p}=0.027)$, high family income $(\mathrm{b}=-1.32 ; 95 \% \mathrm{CI}=-$ 2.61 to $-0.04 ; \mathrm{p}=0.072)$, strong social support $(\mathrm{b}=-1.50 ; 95 \% \mathrm{CI}=-2.92$ to $-0.09 ; \mathrm{p}=0.036)$, good maternal nutritional status $(b=-2.01 ; 95 \% \mathrm{CI}=-3.26$ to $-0.76 ; \mathrm{p}=0.002)$, strong social capital $(\mathrm{b}=$ $-1.45 ; 95 \% \mathrm{CI}=-2.82$ to $-0.08 ; \mathrm{p}=0.038)$, and maternal occupation $(\mathrm{b}=-1.43 ; 95 \% \mathrm{CI}=-2.98$ to $0.12 ; \mathrm{p}=0.072)$. Community health center had contextual effect on LBW with ICC $=20 \%$.

Conclusions: Maternal age $<20$ or $\geq 35$ years, prenatal stress, and exposure to cigarette smoke increase the risk of LBW. LBW decreases with high maternal education, high family income, strong social support, good maternal nutritional status, strong social capital, and maternal occupation. Community health center has contextual effect on LBW.
\end{abstract}

Keywords: low birth weight, stress, social support, community health center

\section{Correspondence:}

Baiq Zulvita Rahayu. Masters Program in Public Health, Universitas Sebelas Maret. Jl. Ir. Sutami No. 36 A, Surakarta, Central Java 57126, Indonesia. Email: rahayubaiq.zulvita@yahoo.co.id.

Mobile: +6281917744469

\section{BACKGROUND}

WHO defines low birth weight (LBW) as the weight of a baby at birth less than 2500 grams. Low birth weight continues to be a significant health problem globally and is associated with short-term and long-term risks posed (WHO, 2014). Mothers who have a high biopsychosocial risk have an influence on the condition of the baby being born, that is, they can be at risk for the health condition of the baby throughout life, so the implementation of interventions in high-risk groups is needed (Fleuriet and Sunil, 2015).

World Health Organization (WHO) stated that 4.2 million or $75 \%$ of all underfive deaths occured in the first year of life and there were 30.5 deaths per 1000 live 
births in 2016 (WHO, 2017). The 2015 Intercensal Population Survey (SUPAS) showed that the Infant Mortality Rate (IMR) in Indonesia was 22.23 per 1 ,000 live births (Ministry of Health of the Republic of Indonesia, 2017). More than 20 million babies worldwide are 15.5 percent of all births born with low birth weight. 95.6 percent of babies with low birth weight are in developing countries, low birth weight rates in developing countries are 16.5 percent, which is more than double that in developed countries at 7 percent (WHO, 2016). The high incidence of low birth weight babies has a significant contribution in the level of neonatal and infant mortality, because these babies with low birth weight (LBW) have a higher risk of early growth retardation, infectious diseases, developmental delay and death during infancy and childhood (WHO, 2016).

Basic health research in 2013 showed that the percentage of low birth weight in Indonesia was $10.2 \%$ (RI Ministry of Health, 2013). In West Nusa Tenggara itself in 2016 the number of cases of infant mortality was 1,006 cases out of 103,132 live births, the highest number of infant deaths occurred in East Lombok which was 467 deaths in 2016 (NTB Health Profile, 2017). In the East Lombok Regency, the largest cases of neonatal death were caused by LBW of 183 cases (47.04\%). The development of LBW babies in 2011 - 2015 experienced a relatively upward trend, namely in 2011-2012 of 3.40\%; 2013-2014 amounting to $3.48 \%$; and in 2015 amounted to 3.68\% (East Lombok District Health Profile, 2016).

Low birth weight has several determinants such as maternal age, education, ANC status, employment, and socio-economic conditions (Mahumud, Sultana and Sarker, 2017). The situation of husbands who smoke can also affect the incidence of low birth weight (Taywade and Pisudde, 2016). Low socio-economic conditions can trigger stress during pregnancy and can affect fetal development in the womb, if not treated properly it will cause low birth weight (Nkansah-amankra, 2017).

The results of the preliminary study showed that the number of LBW cases in 2017 were 789 cases and 115 deaths due to LBW. In January-July 2018, there were 543 cases of LBW and resulted in 56 cases of death.

\section{SUBJECTS AND METHOD}

\section{Research Design}

This study is an observational analytic study with a cross sectional design. The study was conducted in East Lombok Regency, West Nusa Tenggara, Indonesia in September - November 2018.

\section{Population and Samples}

The source population was infants in East Lombok, Indonesia. A sample of 200 infants aged o-3 months was selected for this study by random sampling. 200 subjects were selected, coming from 8 subjects in each level 2 unit, 25 health centers.

\section{Study Variables}

The dependent variable was low birth weight (LBW). The independent variables were maternal age, maternal education, maternal occupation, maternal nutritional status, family income, exposure to cigarette smoke, prenatal stress, social support, and social capital.

\section{Operational Definition of Variables}

Low birth weight was defined as infant birth weight less than 2,500 grams. The measurement scale was continuous and transformed into dichotomous, coded o for LBW $(<2500 \mathrm{~g})$ and 1 for normal birth weight ( $\geq 2500 \mathrm{~g})$. 
Maternal age was defined as age of mother when giving birth. The measurement scale was continuous and transformed into dichotomous, coded o for 20-35 years and 1 for $<20$ years or $>35$ years.

Maternal education was defined as the highest formal education attained by mother. The measurement scale was continuous and transformed into dichotomous, coded o for <senior high school and 1 for $\geq$ senior high school.

Maternal occupation was defined as maternal working status. The data were measured by questionnaire. The measurement scale was categorical, coded o for working at home and 1 for working outside the house.

Family income was defined as the amount of family income received in one month as a source of family economy. The measurement scale was continous and transformed into dichotomous, coded o for $<\operatorname{Rp~1,637,000~and~} 1$ for $\geq \operatorname{Rp~1,637,000.~}$

Maternal nutritional status was measured by maternal mid-upper arm circumference (MUAC) at pregnancy. Data on maternal MUAC were obtained from maternal and child health book. The measurement scale was continous and transformed into dichotomous, coded o for MUAC $<23.5$ $\mathrm{cm}$ and 1 for $M U A C \geq 23.5 \mathrm{~cm}$.

Prenatal stress was defined as the emotional state of the mother during pregnancy. It was measured using Perceived Stress Scale (PSS) by Cohen et al. (1994). The measurement scale was continous and transformed into dichotomous, coded o for low stress (score <13) and 1 for high stress (score $\geq 13$ ).

Exposure to cigarette smoke was defined as a situation in which mothers are often exposed to cigarette smoke caused by slurred home members, work mate, and public place. The data were collected by questionnaire. The measurement scale was continous and transformed into dichotomous, coded o for (score <3) and 1 for (score $\geq 3$ ).

Social capital was defined as a social environment in a social environment involving the involvement in community organization, relationships between relatives, and the existence of trust in a community environment. It was measured by questionnaire. The measurement scale was continous and transformed into dichotomous, coded o for low (score <20) and 1 for high (score $\geq 20$ ).

Social support was defined as the existence of support from family, friends, partners, and community during pregnancy. It was measured by questionnaire. The measurement scale was continous and transformed into dichotomous, coded o for weak (score $<18$ ) and 1 strong (score $\geq 18$ ).

\section{Data Analysis}

Univariate analysis was performed to see the frequency distribution and the percent of sample characteristics. Bivariate analysis was conducted to study the relationship between LBW and independent variables using the chi-square test and calculated of odds ratios (OR) with 95\% confidence (CI). Furthermore, multivariate analysis was performed using a multilevel logistic regression.

\section{Research Ethics}

The research ethics include informed consent, anonymity, confidentiality and ethical clearance. The ethical clearance was obtained from Research Ethics Committee, Faculty of Medicine, Universitas Sebelas Maret, Surakarta, Central Java, Indonesia with number 383 / UN27.6 / KEPK / 2018.

\footnotetext{
RESULTS

1. Sample characteristics

Table 1 showed sample characteristics. Table 1 showed that the majority of mothers aged $<20$ or $>35$ years were 121 (60.5\%)
} 
and as many as $70.5 \%$ working at home. As many as 145 infants (72.5\%) were at age $\geq 8$ weeks. Most of infants were female (56.3\%).

Table 1. sample characteristics

\begin{tabular}{|c|c|c|}
\hline Characteristics & (n) & (\%) \\
\hline \multicolumn{3}{|l|}{ Maternal age } \\
\hline$<20$ or $>35$ years & 121 & 60.5 \\
\hline 20-35 years & 79 & 39.5 \\
\hline \multicolumn{3}{|l|}{ Infants age } \\
\hline$<8$ weeks & 55 & $27 \cdot 5$ \\
\hline$\geq 8$ weeks & 145 & 72.5 \\
\hline \multicolumn{3}{|l|}{ Infants gender } \\
\hline Male & 87 & 43.5 \\
\hline Female & 113 & 56.5 \\
\hline \multicolumn{3}{|c|}{ Amaternal occupation } \\
\hline Housewife & 141 & 70.5 \\
\hline Farmer & 32 & 16 \\
\hline Seller/entrepreneur & 10 & 5 \\
\hline employee & 17 & 8.5 \\
\hline
\end{tabular}

\section{Bivariate Analysis}

Table 2 showed the results of bivariate analysis. Table 2 showed that there was a relationship between maternal age and LBW. Maternal age $<20$ or $>35$ years increased the risk of $\mathrm{LBW}(\mathrm{OR}=3.09$; 95\% $\mathrm{CI}=1.60$ to $5.98 ; \mathrm{p}=0.001$ ).

There was a relationship between maternal education and LBW. High maternal education lowered the risk of LBW $(\mathrm{OR}=0.20 ; 95 \% \mathrm{CI}=0.09$ to $0.42 ; \mathrm{p}=$ 0.001).

There was a relationship between maternal occupation and LBW. Mother who working outside the house lowered the risk of LBW, but it was statistically non-significant $(\mathrm{OR}=0.52 ; 95 \% \mathrm{CI}=0.22$ to $1.21 ; \mathrm{p}=$ o.180).

Table 2. The results of bivariate analysis

\begin{tabular}{|c|c|c|c|c|c|c|c|}
\hline \multirow{3}{*}{ Independent variables } & \multicolumn{4}{|c|}{ LBW } & \multirow{3}{*}{$\mathbf{O R}$} & \multirow{3}{*}{ CI 95\% } & \multirow{3}{*}{$\mathbf{p}$} \\
\hline & \multicolumn{2}{|c|}{ Yes } & \multicolumn{2}{|c|}{ No } & & & \\
\hline & $\mathrm{n}$ & $\%$ & $\mathrm{~N}$ & $\%$ & & & \\
\hline \multicolumn{8}{|l|}{ Maternal age } \\
\hline 20-35 years & 20 & 16.53 & 101 & 83.56 & 3.09 & $1.60-5.98$ & 0.001 \\
\hline$<20$ or $>35$ years & 30 & 8 & 49 & 2 & & & \\
\hline \multicolumn{8}{|l|}{ Maternal education } \\
\hline$<$ Senior high school & 38 & 39.2 & 59 & 60.8 & 0.20 & $0.09-0.42$ & 0.001 \\
\hline$\geq$ Senior high school & 12 & 11.7 & 91 & 88.3 & & & \\
\hline \multicolumn{8}{|l|}{ Maternal occupation } \\
\hline At home & 42 & 27.5 & 110 & 72.4 & 0.52 & $0.22-1.21$ & 0.180 \\
\hline Outside of home & 8 & 16.7 & 40 & 83.3 & & & \\
\hline \multicolumn{8}{|l|}{ Family Income } \\
\hline Low & 32 & 35.6 & 58 & 64.4 & 0.35 & $0.18-0.69$ & 0.003 \\
\hline High & 18 & 16.4 & 92 & 83.6 & & & \\
\hline \multicolumn{8}{|l|}{ Maternal MUAC } \\
\hline$<23.5 \mathrm{~cm}$ & 38 & 52.1 & 35 & 47.9 & 0.96 & $0.45-0.20$ & 0.001 \\
\hline$\geq 23.5 \mathrm{~cm}$ & 12 & 9.4 & 115 & 90.6 & & & \\
\hline Prenatal Stress & & & & & & & 0.001 \\
\hline Low & 21 & 14.9 & 120 & 85.1 & 5.52 & $2.78-11.00$ & \\
\hline High & 29 & 49.2 & 30 & 50.8 & & & \\
\hline \multicolumn{8}{|l|}{ Smoke exposure } \\
\hline Low & 12 & 10.4 & 103 & 89.6 & 6.94 & $3 \cdot 32-14 \cdot 47$ & 0.001 \\
\hline High & 38 & 44.7 & 47 & $53 \cdot 3$ & & & \\
\hline \multicolumn{8}{|l|}{ Social Capital } \\
\hline Low & 33 & 44.6 & 41 & $55 \cdot 4$ & 0.19 & $0.98-0.38$ & 0.001 \\
\hline High & 17 & 13.5 & 109 & 86.5 & & & \\
\hline \multicolumn{8}{|l|}{ Social Support } \\
\hline Weak & 35 & 50.7 & 34 & 49.3 & 0.12 & $0.06-0.26$ & 0.001 \\
\hline Stromg & 15 & 11.5 & 116 & 88.5 & & & \\
\hline
\end{tabular}


There was a relationship between family income and LBW. High family income lowered the risk of $\mathrm{LBW}(\mathrm{OR}=0.35$; $95 \% \mathrm{CI}=0.18$ to $0.69 ; \mathrm{p}=0.003$ ).

There was a relationship between maternal MUAC and LBW. Maternal MUAC $\geq 23.5 \mathrm{~cm}$ reduced the risk of LBW $(\mathrm{OR}=0.96 ; 95 \% \mathrm{CI}=0.45$ to $0.20 ; \mathrm{p}=$ o.001).

There was a relationship between prenatal stress and LBW. High maternal stress during pregnancy increased the risk of $\mathrm{LBW}(\mathrm{OR}=5.52 ; 95 \% \mathrm{CI}=2.78$ to 11.00 ; $\mathrm{p}=0.001)$.

There was a relationship between cigarette smoke exposure and LBW. Infant with high exposure to cigarette smoke was more likely to had birth weight $<2,500 \mathrm{~g}$
$(\mathrm{OR}=6.94 ; 95 \% \mathrm{CI}=3.32$ to $14.47 ; \mathrm{p}=$ 0.001).

There was a relationship between social capital and LBW. High social capital reduced the risk of $\mathrm{LBW}(\mathrm{OR}=0.19 ; 95 \%$ $\mathrm{CI}=0.98-0.38 ; \mathrm{p}=0.001)$.

There was a relationship between social support and LBW. High social support reduced the risk of $\mathrm{LBW}(\mathrm{OR}=$ $0.12 ; 95 \% \mathrm{CI}=0.06-0.26 ; \mathrm{p}=0.001)$.

\section{Multivariate Analysis}

Table 3 showed the results od multilevel analysis. Table 3 showed that there was a positive effect of maternal age and LBW $(b=$ 2.60; 95\% CI $=0.96$ to $4.25 ; \mathrm{p}=0.002$ ). Maternal age $<20$ or $>35$ years more likely had LBW infants.

Table 3. The results of multilevel logistic regression analysis

\begin{tabular}{lccccc}
\hline \multirow{2}{*}{ Independent Variables } & \multicolumn{5}{c}{$\mathbf{9 5 \%}$ CI } \\
\cline { 2 - 6 } Fixed Effect & b & SE & Lower Limit & Upper Limit & p \\
Maternal Age & & & & & \\
Maternal Education & 2.60 & 0.84 & 0.96 & 4.25 & 0.002 \\
Maternal Employment & -1.37 & 0.62 & -2.60 & -0.15 & 0.027 \\
Family Income & -1.42 & 0.79 & -2.98 & 0.12 & 0.072 \\
Nutritional Status & -1.32 & 0.65 & -2.61 & -0.47 & 0.042 \\
Prenatal Stress & -2.01 & 0.63 & -3.25 & -0.77 & 0.002 \\
Cigarette Smoke Exposure & 1.30 & 0.65 & 0.01 & 2.58 & 0.048 \\
Social Capital & 1.56 & 0.61 & 0.37 & 2.76 & 0.010 \\
Social Support & -1.44 & 0.70 & -2.60 & -0.15 & 0.027 \\
Random Effect & -1.50 & 0.72 & -2.91 & -0.09 & 0.036 \\
Community Health Center & & & & & \\
Var(constants) & & & & & \\
N observation= 200 & 0.83 & 1.39 & 0.03 & & \\
N group= 25 & & & & & \\
Log likelihood= -51.43 & & & & & \\
P= 0.001 & & & & & \\
ICC= 20\% & & & & & \\
\hline
\end{tabular}

There was a negative effect of maternal education and LBW $(b=-1.38$; 95\% CI= -2.60 to $-0.15 ; \mathrm{p}=0.027$ ). Maternal education $\geq$ senior high school reduced the risk of LBW.

There was a negative effect of maternal employment and LBW $(b=-1.43 ; 95 \%$
$\mathrm{CI}=-2.98$ to $0.12 ; \mathrm{p}=0.072)$. Mothers who worked at home reduced the risk of LBW.

There was a negative effect of family income and $\mathrm{LBW}(\mathrm{b}=-1.32 ; 95 \% \mathrm{CI}=-2.61$ to $-0.04 ; p=0.072)$. High family income lowered the risk of LBW.

There was a negative effect of maternal MUAC and LBW (b= -2,01; 95\% CI= - 
3.26 to $-0.76 ; \mathrm{p}=0.002)$. Maternal MUAC $\geq 23.5 \mathrm{~cm}$ reduced the risk of LBW.

There was positive effect of prenatal stress and LBW $(b=1.30 ; 95 \% \mathrm{CI}=0.01$ to 2.57; $\mathrm{p}=0.048)$. High prenatal stress increased the risk of LBW.

There was positive effect of cigarette smoke exposure and LBW $(b=1.57 ; 95 \%$ $\mathrm{CI}=0.37$ to $2.76 ; \mathrm{p}=0.010$ ). High cigarette smoke exposure increased the risk of LBW.

There was negative effect of social capital and LBW $(b=-1.45 ; 95 \% \mathrm{CI}=-2.82$ to $-0.08 ; \mathrm{p}=0.038)$. High social capital reduced the risk of LBW.

There was negative effect of social support and LBW $(b=-1.50 ; 95 \% \mathrm{CI}=-2.92$ to $-0.09 ; \mathrm{p}=0.036)$. Strong social support lowered the risk of LBW.

Community health center had contextual effect on LBW (ICC $=20 \%)$.

\section{DISCUSSION}

1. The effect of maternal age on $\mathrm{LBW}$ The result of this study showed that maternal age $<20$ or $>35$ years were more likely to deliver LBW infants than maternal age 20-35 years.

The result of this study was in line with a study by Awintuen et al. (2018) which showed that maternal age was the determinant of low birth weight incident in infants. Mothers aged less than 20 years old have less physical and emotional maturity and their ignorance to protect themselves during pregnancy so that they can contribute to giving birth to low birth weight babies. Mothers over the age of 35 years old have a tendency to experience complications in pregnancy that could lead to low birth weight babies (Ngwira and Stanley, 2015).

2. The effect of maternal education on LBW

The result of this study showed that high maternal education reduced the risk of
LBW. The result of this study was supported by a study by Ngwira and Stanley (2015) which stated that there was an effect of maternal education on the incidence of low birth weight in infants. Low level of education limited the access to information about nursing during pregnancy. Low education also created a lack of knowledge of good and healthy food pattern which caused a poor dietary pattern.

Lower maternal education was associated to poor utilization of prenatal care services and low nutritional food intake and thus can increase the risk of low birth weight in babies (Acharya et al., 2018). Maternal education was the initial health capital that can be related to educational associations with health-related resources. Mothers who were highly educated tend to have different health inputs than mothers who have low level of education which can have an impact on babies (Kim and Wickrama, 2016).

\section{The effect of maternal employment on LBW}

The result of this study showed that there was no significant effect of maternal employment on the incidence of low birth weight in infants. The result of this study was supported by a study by Taywade et al (2016) which stated that there was no effect of maternal employment on the incidence of low birth weight in Wardha, India.

\section{The effect of family income on LBW}

The result of this study showed that there was a significant effect of family income on the incidence of LBW. Infants who were born in high income family had a lower risk of LBW. The level of income determined the type of diet food consumed, the greater the family income, the greater the ability to fulfill the nutrition for nutritious food (Ngwira and Stanley, 2015). 
This study was in line with a study by Rahma et al. (2016) which reported that family income below minimum wage had a significant effet on the incidence of LBW $(b=-1.22 ; 95 \% \mathrm{CI}=-227$ to $-0.18 ; \mathrm{p}=0.022)$. Infants who were born to high family income had lower risk of LBW by 1.22 units.

\section{The effect of maternal nutritional status on LBW}

The result of this study showed that there was a significant effect of good maternal nutritional status on the incidence of low birth weight in infants. Mothers with MUAC $<23.5 \mathrm{~cm}$ at pregnancy had higher risk to give birth LBW infants.

This study was in line with a study done by Ms et al. (2018) which stated that maternal nutritional status has an effect on the incidence of low birth weight in infant $(b=-1.49 ; 95 \% \mathrm{CI}=-2.32$ to $-0.65 ; \mathrm{p}$ $<0.001)$. Good maternal nutritional status can reduce the risk of giving birth to a low birth weight baby by 1.49 units. Adequacy of healthy food nutrition during pregnancy affected the weight of the baby. Maternal nutritional status both before pregnancy orduring pregnancy was a determining factor in fetal development and maternal health. A child with a mother who was short, thin, or anemic was more likely to experience growth restriction in the uterus and low birth weight (Black, 2013). Adequate nutritional status in the period of pregnancy and even after childbirth seemed to be due to the quality and frequency of follow-up to mothers by public health center (Ana et al., 2018).

\section{The effect of prenatal stress on LBW}

The result of this study showed that there was a significant effect of prenatal stress on LBW. Mothers with high prenatal stress were more likely to give birth LBW infants.
The result of this study was supported by a study by Trisnawati et al., (2017) which stated that mothers who experienced stress during pregnancy have a risk to increase the incidence of low birth weight in infants. The effort that can be done was to visit health services or share with the surrounding environment if there were problems experienced during pregnancy so that it would not cause stress.

High levels of prejudice, status inconsistency, or stress acculturation ultimately lead to poor mental and physical health (Emmen et al., 2013; Gibbons et al., 2014; Halim et al., 2013), so that a mother who has a mental and physical health problem could affect the baby.

\section{The effect of cigarette smoke expo- sure on LBW}

The result of this study showed that there was a significant effect of cigarette smoke exposure on LBW. High cigarette exposure during pregnancy increased the risk of LBW.

This study was in line with a study by Mine et al., (2017) which reported that mothers who smoke during pregnancy had a significant effect on LBW. Other sources of exposure to cigarette smoke such as cigarette smoke in the environment, including cigarette smoke in the workplace and passive smoke from other smoking family members also negatively affected the neonates which associated with low birth weight babies.

The existence of regulations on the prohibition of smoking in public places can reduce the incidence of low birth weight babies. Díez-izquierdo et al., (2017) stated that the existence of a smoking prohibition in public places can reduce the risk of premature babies which associated with a low incidence of low birth weight babies. 


\section{The effect of social capital on LBW} study showed that there was an effect of social capital on the incidence of low birth weight in infants. Mothers with low social capital were more likely to give birth to low birth weight babies. Social capital was a social relationship between individuals and mutual trust, reciprocal assistance and involvement inherent in the relationships that exist in the community. Individuals tend to establish social relations with a similar background in socio-economic, racial/ethnic status. When living in an environment with a diverse background, individuals were more likely to interact with other citizens, build social bond, and provide support both emotionally and real. As a result, ethnic density facilitated someone's social capital. Good social capital has the some advantages, which were faciletating the diffusion of health information (for example, preventive health services and new care) and reducing barriers to health services (for example, the neighbors who offer transportation to health facilities), having good social relations which lead to good quality of life, and reducing stress in everyday life (Yang, Lei and Kurtulus, 2018).

\section{The effect of social support on LBW}

The result of this study showed that there was a significant effect of social support on the incidence of low birth weight in infants. Mothers with low social support have higher risk to give birth to low birth weight babies compared to mothers with high social supports from friends, husbands, families, andpeople in the surrounding environment.

Social support during pregnancy was closely related to depression in pregnancy, where depression during pregnancy can affect the weight of the babies. The need for social support during pregnancy was felt differently from the situation before pregnancy, social support in each period of pregnancy was an important buffer to the depression in pregnancy (Li et al., 2017). High social support from partners, families, and friends in the surrounding environment can also reduce prenatal stress, this was in line with the study of Tengteng et al. (2018) which stated that social support from partners and families was an important element in the social support system which can protect from prenatal stress.

\section{The effect of community health center on LBW}

The result of this study showed that there was a contextual effect of community health center on LBW by $20 \%$.

One of the efforts to increase public access to quality health services was by increasing the access to basic health services. The role of the health center and its network as an institution that provided health services at the first level which was directly involved with the community was very important (Minister of Health RI, 2016). According to the Minister of Health RI Regulation Number 46 of 2015, the establishment of community health center accreditation status consisted of (a) not accredited, (b) basic accreditation, (c) madya accreditation, (d) utama accreditation, (e) paripurna accreditation (Minister of Health RI, 2015).

The effect of the community health center was inseparable from of health personnel performance. A study by Sujana et al. (2018) concluded that the role of health personnels in implementing existing programs to reduce newborn morbidity and mortality rates such as early detection of high risk newborns, conducting initiati and strategies in problem solving, was proven to reduce the number of infant mortality.

One of the determinants of LBW in this study was the relationship between the 
age of young mothers (<20 years old). A study by Ramadani et al., (2015) stated that there was a relationship between gestational age in adolescence and the role of health personnel. Health personnel played an important role as educators to be able to carry out the role in conducting counseling about the risks that occur in adolescences' pregnancies, and can provide guidance and encouragement to adolescents in order to avoid pregnancy in adolescence.

One of the roles of health personnels was to optimize ANC services. Adequate ANC services and high ANC frequencies in pregnant women can reduce the risk of giving birth to LBW infants, because during ANC visits, pregnant women can be early detected in the risk of pregnancy, get more information about pregnancy, especially in terms of nutrition for pregnant women. A study by Nyamasege et al. (2018) stated that nutritional counseling and good ANC visits could reduce the risk in pregnancy.

$\frac{\text { REFERENCE }}{\text { Acharya D, Singh J, Kadel R, Yoo SJ, Park }}$ $\mathrm{JH}$, Lee K (2018). Maternal Factors and utilization of the antenatal care services during pregnancy associated with low birth weight in rural Nepal: analyses of the antenatal care and birth weight. International Journal of Environmental Research and Public Health, 15(11)24: 1-14. doi: 10.3390/ijerph15112450.

Ana S, et al. (2018). Predictors of excess birth weight in Brazil: a systematic review. Jornal de Pediatria. Sociedade Brasileira de Pediatria. doi: 10.1016/j.jped.2018.04.06.

Awintuen I, et al. (2018). Socio demographic determinants of low birth weight: Evidence from the Kassena-Nankana districts of the Upper East Region of Ghana. PLoS one. 13(11): 1-10. doi: http://doi.org/10.1371/journal.poe.02 06207.

Black RE, Victora CG, Walker SP, Bhutta ZA, Christian P, de Onis M, Uauy R (2013). Maternal and child undernutritionand overweight in lowincome and middle-income countries. The Lancet, 382(9890): 427-451. doi: 10.1016/s0140-6736(13)60937-X

Dinas Kesehatan Kabupaten Lombok Timur (2016). Profil Kesehatan Lombok Timur Tahun 2015. Selong: Dinas Kesehatan Lombok Timur.

Dinas Kesehatan Provinsi NTB (2017). Profil Kesehatan NTB tahun 2016. Mataram: Dinas Kesehatan Provinsi NTB.

Díez-izquierdo A, et al. (2017). Correlation between tobacco control policies and preterm births and low birth weight in Europe. Environmental Research. Elsevier Inc. 1-6. doi: 10.1016/j.envres.2017.10.033.

Fleuriet KJ, Sunil TS (2015). Reproductive habitus, psychosocial health, and birth weight variation in Mexican immigrant and Mexican American women in south Texas. Social Science and Medicine. Elsevier Ltd, 138: 102109. doi: 10.1016/j.socscimed.2015.05.043.

Islam MM, ElSayed MK (2015). Pattern and determinants of birth weight in Oman. Public Health, 129(12), 16181626.

Kementerian Kesehatan RI (2015). Peraturan Menteri Kesehatan Republik Indonesia Nomor 46 Tahun 2015 tentang akreditasi puskesmas, klinik pratama, tempat praktik mandiri dokter, dan prakter mandiri dokter gigi. Jakarta.

Kim J, Wickrama KAS (2016). Maternal social status, early health capital, and 
young adults' economic attainment: Early life course investigation. Social Science Research. Elsevier Ltd. doi: 10.1016/j.ssresearch.2016.06.022.

Li Y, Long Z, Cao D, Cao F (2017). Social support and depression across the perinatal period: A longitudinal study. doi: 10.1111/ijlh.12426.

Mahumud RA, Sultana M, Sarker AR (2017). Distribution and determinants of low birth weight in developing countries. Journal of Preventive Medicine and Public Health, 50(1): 1828. doi: 10.3961/jpmph.16.087.

Mine T, et al. (2017). Maternal smoking during pregnancy and rapid weight gain from birth to early infancy. Journal of Epidemiology. Elsevier Ltd, 27(3): 112-116. doi: 10.1016/j.je.2016.10.005.

Ms NP, Salimo H, Murti B (2018). The effect of biological , social, economic , and nutritional factors on low birth weight: A new path analysis evidence from Madiun Hospital, East Java, Indonesia. Journal of Maternal and Child Health, 3(3): 166-175. doi: https://doi.org/10.26911/thejmch.20 18.03.03.01.

Ngwira A, Stanley CC (2015). Determinants of low birth weight in Malawi: Bayesian Geo-Additive Modelling. PLoS ONE, 10(6): 1-14.

Nkansah-amankra S (2017). Characteristics and birth outcomes in adulthood. Midwifery. Elsevier Ltd. doi: 10.1016/j.midw.2017.12.004.

Nyamasege CK, Wanjohi M, Kaindi DWM (2018). Determinants of low birth weight in the context of maternal nutrition education in urban informal settlements, Kenya, Journal of Developmental Origins of Health and Disease: 1-9. doi: 10.1017/S2040174-
418000715 .

Rahma F, et al. (2018). Path analysis on the biological and social economic determinants of neonatal death in Bantul District, Yogyakarta. Journal of Maternal and Child Health. 3: 91-99. doi: https://doi.org/10.26911/thejmch.2018.03.02.01.

Ramadani M, et al. (2015). Peran tenaga kesehatan dan keluarga dalam kehamilan usia remaja. Jurnal Kesehatan Masyarakat Nasional. 10(94): 87-92.

Sujana T, Dary JDEL (2018). Peran Tenaga Kesehatan Dalam Usaha Pencegahan Kesakitan Dan Kematian Bayi Baru Lahir. Jurnal KesMaDaSka.

Taywade ML, Pisudde PM (2016). Science Direct Study of sociodemographic determinants of low birth weight in Wardha district, India. Clinical Epidemiology and Global Health. 1-7. doi: 10.1016/j.cegh.2016.07.001.

Tengteng Li, Nafei G, Jiang HMEM Zhuang W (2018). Social Support and Second Trimester Depression. Midwifery. Elsevier Ltd.

Trisnawati I, Salimo H, Murti B (2017). Biopsychosocial and economic determinants of low birth weight in Jambi , South Sumatera: Path Analysis. Journal of Maternal and Child Health, 1(1): 1-10. doi: https://doi.org/10.26911/thejmch.2018.03.01.01.

Yang T, Lei L, Kurtulus A (2018). Health \& Place Neighborhood ethnic density and self-rated health: Investigating the mechanisms through social capital and health behaviors. Health \& Place. Elsevier Ltd, 53: 193-202. doi: 10.1016/j.healthplace.2018.08.011.

WHO (2016). Standard formula for lowbirth-weight infants following hospital discharge. http://www.who.int/elena/titles/formula_infants/en/ 